OPEN ACCESS

Edited by:

Briony Forbes,

Flinders University, Australia

Reviewed by:

Rosario Le Moli,

Università degli Studi di Catania, Italy

Giovanni Luca,

University of Perugia, Italy

${ }^{*}$ Correspondence:

Vishnu Garla

vgarla@umc.edu

Specialty section:

This article was submitted to

Cancer Endocrinology,

a section of the journal

Frontiers in Endocrinology

Received: 08 January 2019

Accepted: 01 May 2019

Published: 15 May 2019

Citation:

Garla V, Sonani $H$, Palabindala V,

Gomez-Sanchez C, Subauste $J$ and

Lien LF (2019) Non-islet Cell

Hypoglycemia: Case Series and

Review of the Literature.

Front. Endocrinol. 10:316.

doi: 10.3389/fendo.2019.00316

\section{Non-islet Cell Hypoglycemia: Case Series and Review of the Literature}

\author{
Vishnu Garla ${ }^{1 *}$, Hardik Sonani ${ }^{2}$, Venkatraman Palabindala ${ }^{1}$, Celso Gomez-Sanchez ${ }^{1}$, \\ Jose Subauste ${ }^{1}$ and Lillian Francis Lien ${ }^{1}$
}

${ }^{1}$ Department of Internal Medicine, University of Mississippi Medical Center, Jackson, MS, United States, ${ }^{2}$ Icahn School of

Medicine at Mount Sinai, New York, NY, United States

Non-islet cell hypoglycemia $(\mathrm{NICH})$ is hypoglycemia due to the overproduction of insulin-like growth factor-2 (IGF-2) and its precursors which can activate the insulin receptor. Typically, large mesenchymal and epithelial tumors can cause $\mathrm{NICH}$. Diagnosis is confirmed by finding an elevated IGF-2/IGF-1 ratio. The mainstay of treatment is surgical excision. Glucocorticoids may be used in cases where surgery is not possible. We present two cases of $\mathrm{NICH}$ with different outcomes. A 33-year-old male patient admitted with altered mental. He was found walking naked outside his house. Laboratory assessment revealed severe hypoglycemia. Further evaluation showed low levels of insulin, C-peptide, and beta-hydroxybutyrate along with an elevated IGF-2/IGF-1 ratio confirming the diagnosis of $\mathrm{NICH}$. Computed tomography (CT) of the abdomen showed a massive tumor of the liver consistent with hepatocellular carcinoma. Since the patient refused surgery, he was started on prednisone however the hypoglycemia persisted. A 54-year-old female patient with a history of type 2 diabetes mellitus (DM) admitted with recent onset hypoglycemia. Despite stopping her insulin, she continued to have hypoglycemia necessitating the administration of high concentrations of intravenous dextrose. Further evaluation showed low levels of insulin, C-peptide, and beta-hydroxybutyrate along with an elevated IGF-2/IGF-1 ratio consistent with the diagnosis of $\mathrm{NICH}$. CT abdomen showed a $24 \mathrm{~cm}$ tumor near the uterus. The pathology was consistent with a gastrointestinal stromal tumor (GIST). After surgical excision of the tumor, the hypoglycemia resolved.

Keywords: non-islet cell hypoglycemia, hypoglycemia, hepatocellular carcinoma, gastrointestinal stromal tumor, IGF-2 induced hypoglycemia

\section{INTRODUCTION}

Non-islet cell hypoglycemia (NICH) is a rare cause of hypoglycemia which is due to excessive secretion of insulin-like growth factor (IGF)-2 or pro IGF-2. These molecules can activate the insulin receptor and can cause hypoglycemia. NICH is seen in association with epithelial and mesenchymal tumors. (1) NICH is potentially misdiagnosed or underdiagnosed due to its rarity, non-classical clinical presentation, and an ambigous lab picture. It can cause profound and persistent hypoglycemia until the surgical excision of the tumor is performed, which can potentially influence the management strategy for the treatment of cancer (2).

We report two cases of NICH one secondary to hepatocellular carcinoma and the other due to a gastrointestinal stromal tumor (GIST). 
TABLE 1 | Laboratory assessment of hypoglycemia.

\begin{tabular}{lcc}
\hline & Case 1 & Case 2 \\
\hline Plasma glucose $(74-106 \mathrm{mg} / \mathrm{dl})$ & 34 & 54 \\
Insulin $(2-25 \mu \mathrm{U} / \mathrm{l})$ & $<1$ & $<1$ \\
C peptide $(0.78-5.19 \mathrm{ng} / \mathrm{ml})$ & 0.04 & 0.25 \\
Proinsulin (3-20 pmol/l) & 2.3 & 2.9 \\
Beta hydroxybutyrate $(0.2-2.81 \mathrm{mg} / \mathrm{dl})$ & 0.71 & 0.35 \\
Insulin antibodies $(0.00-0.02 \mathrm{nmol} / \mathrm{ml})$ & 0 & 0 \\
Sulfonylurea screen & Negative & Negative \\
IGF-1 (108-167 ng/ml) & 23 & 54 \\
IGF-2 (288-736 ng/ml) & 506 & 609 \\
IGF-2/IGF-1 ratio & 22 & 11.27 \\
\hline
\end{tabular}

\section{CASE 1}

A 33-year-old Hispanic male who was brought to the emergency room with altered mental status. He was found by his coworkers to be incoherent and was walking naked outside his home. Blood glucose was low at $29(74-106 \mathrm{mg} / \mathrm{dl})$. He had persistent hypoglycemia despite receiving several ampoules of $50 \%$ dextrose. A $5 \%$ dextrose infusion was started which maintained glucose in the normal range. The patient did have some improvement in his mental status but not complete normalization. He denied any history of diabetes mellitus, alcohol abuse, or illegal drug use. History was significant for a 30lb weight loss over the last 4 months. The physical examination was significant for a stellate laceration in the occipital region and marked hepatomegaly. He was oriented to time, place and person. Ultrasound of the abdomen revealed a $15 \mathrm{~cm}$ mass in the left lobe of the liver concerning for malignancy. Elevated alpha-fetoprotein and liver biopsy both were consistent with the diagnosis of hepatocellular cancer. Further laboratory assessment for the evaluation of hypoglycemia showed low insulin, c peptide, proinsulin, and beta-hydroxybutyrate. Insulin antibodies and sulfonylurea screen were negative. Insulin-like growth factor 2 (IGF-2) was normal; however, the insulin-like growth factor1 (IGF-1) was suppressed. The IGF-2/IGF-1 ratio was $>10$, consistent with the diagnosis of NICH (Table 1). Computed tomography (CT) of the chest and abdomen showed a large mass of $20 \mathrm{~cm}$ size in the liver and a solitary nodule in the right lung which was consistent with metastasis (Figure 1). Since the patient continued to be hypoglycemic, he was started on glucocorticoids (initially hydrocortisone and then prednisone to a maximum dose of $40 \mathrm{mg}$ ). Despite this, the patient continued to have hypoglycemic episodes (Figure 2). A bone scan revealed further metastasis in the right clavicle and scapula. Palliative debulking of the tumor was considered however was deferred per the patient's wishes.

\section{CASE 2}

A 54-year-old African American female patient who was transferred to our hospital for evaluation of hypoglycemia. Her past medical history was significant for diabetes mellitus on 10 units glargine nightly, end-stage renal disease on hemodialysis, hypertension, and uterine fibroids. Before the admission, she had hypoglycemic episodes for the last 2 weeks which persisted even after she stopped taking her insulin. These hypoglycemic episodes were characterized by sweating, anxiety, and confusion. A $20 \%$ dextrose infusion, but her hypoglycemia persisted. Initially, inadvertent intake of insulin or persistence of insulin due to renal failure were thought to be the cause of hypoglycemia. However, low plasma insulin, proinsulin, c peptide, and betahydroxybutyrate all pointed toward hypoglycemia secondary to a non-islet cell tumor (Table 1). IGF-1 was suppressed with a normal IGF-2 however the molar ratio was high confirming the diagnosis of IGF-2 induced hypoglycemia. CT abdomen revealed a $24 \mathrm{~cm}$ mass adjacent to the uterus (Figure 1). Hypoglycemia was persistent and necessitated the use of high concentration of dextrose (D) solution (up to D 70\%) and multiple administration of rescue D 50\% ampoules (Figure 2). A core biopsy was performed, and the pathology was consistent with a gastrointestinal stromal tumor (GIST). During exploratory laparotomy, a large vascular mass adherent to the sigmoid colon was observed. Excision of the mass along with a sigmoid colectomy with a colostomy, hysterectomy, oophorectomy, and an appendectomy was performed. Postoperatively she was hyperglycemic, and the dextrose infusion was discontinued. Pathology confirmed the diagnosis of GIST of the small intestine which stained positively for IGF-2 (Figure 3). Upon follow up in the endocrine clinic after 2 months she was euglycemic on her original home insulin regimen.

\section{DISCUSSION}

Hypoglycemia can be secondary to diverse etiologies; however, it is most often seen in diabetic patients on insulin or insulin secretagogues. NICH is a rare cause of hypoglycemia due to excessive secretion of IGF-2 or pro-IGF-2 $(3,4)$. NICH was first described in 1929 in a patient with hepatocellular carcinoma (5). Hypoglycemia was believed to be due to excessive consumption of glucose by the tumor until Unger et al. (6) suggested it was secondary to a humoral factor. Megyesi et al. demonstrated the presence of IGF in the tumor and also the resolution of hypoglycemia after excision of the tumor (7). Rinerkencht isolated IGF-1 and IGF-2 in 1978 while Dughaday et al. described NICH with normal IGF-2 but high pro-IGF-2 levels $(8,9)$.

$\mathrm{NICH}$ is mostly seen in mesenchymal and epithelial tumors. The most common tumor to be associated with $\mathrm{NICH}$ is hepatocellular carcinoma. However, the list of tumors associated with $\mathrm{NICH}$ is steadily increasing (Table 2). Most of these tumors are large; Both, benign, and malignant tumors have been associated with $\mathrm{NICH}$ (4). With the increasing incidence of hepatocellular cancer, the incidence of NICH is expected to increase but has remained steady, likely secondary to under diagnosis (10).

Typically in patients with IGF-2 induced hypoglycemia, the levels of insulin, and IGF-1 are low whereas the level of IGF-2 can be normal or elevated (11). For a long time the mechanism 


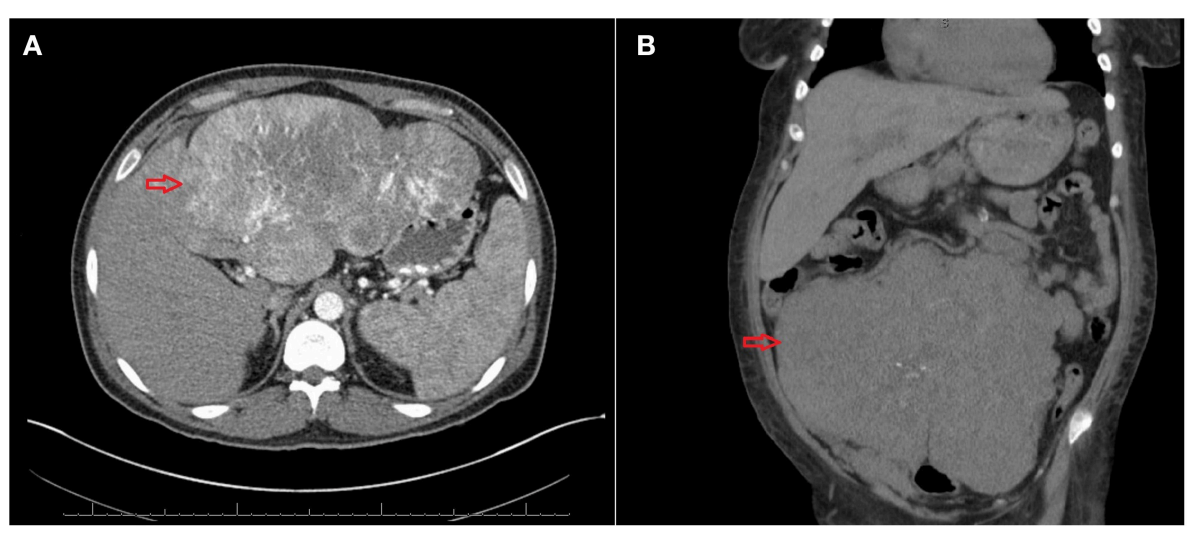

FIGURE 1 | (A) Computed tomography (CT) of the abdomen showing a large mass of $20 \mathrm{~cm}$ size (red arrow). (B) CT of the abdomen showing a large tumor of 24 $\mathrm{cm}^{*} 18 \mathrm{~cm}^{*} 12 \mathrm{~cm}$ (red arrow).
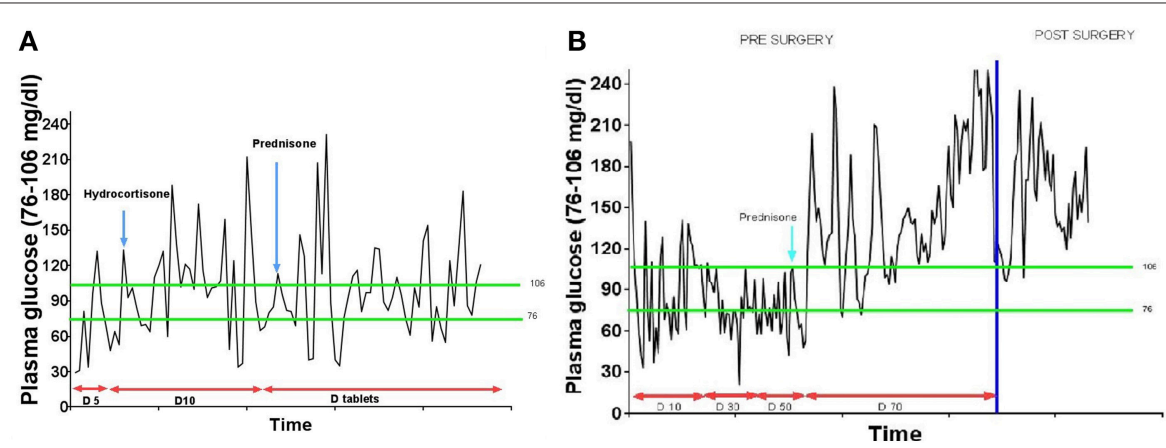

FIGURE 2 | (A) Plasma glucose trend in case 1. (B) Plasma glucose trend in case 2.

by which a normal IGF-2 could cause hypoglycemia remained a mystery, till the identification of an incompletely processed pro-IGF-2 (aka big IGF-2) in 1988 (9). IGF-2omas can secrete excessive quantities of pro-IGF-2 due to loss of imprinting secondary to activation of abnormal promoters. This relative excess of pro-IGF-2 may overwhelm the enzymes which usually process pro IGF-2 to mature IGF-2 (11-13).

Hypoglycemia may be the presenting symptom in approximately half the patients with IGF-2 producing tumors. In other cases, the diagnosis of cancer may precede the hypoglycemia $(14,15)$. Typically hypoglycemia is seen in the fasting state. Due to the repeated attacks of hypoglycemia, neuroglycopenic symptoms can predominate. Confusion, psychosis, amnesia, and seizures can be the presenting symptoms of NICH. Our first patient presented with confusion and amnesia likely due to the repeated attacks of hypoglycemia (16). $\mathrm{NICH}$ needs to be considered along with opioid use, cerebral metastasis, and infections in any cancer patient with altered mental status. NICH tends to have more severe symptoms than fasting hypoglycemia at the same glucose level due to the lack of ketogenesis secondary to the activation of the insulin receptor (IR) by IGF-2 (17). Acromegaloid changes secondary to the activation of IGF receptors by IGF-2 have been described in rare instances. Trivedi et al. reported a patient with pelvic clear cell sarcoma who developed acromegaloid changes which resolved after excision of the tumor (18).

$\mathrm{NICH}$ is secondary to excessive secretion of IGF-2 or pro-IGF2. While IGF-2's role in fetal development is well-known, but its role in adults is less well-defined $(19,20)$. The IGF-2 gene is located on the short arm of chromosome 11 between the insulin and H19 genes (21). This gene is translated into a pre-pro IGF-2 peptide which consists of a 24 amino acid $\mathrm{N}$ terminal, 67 amino acid mature IGF-2, and an 89 amino acid $\mathrm{C}$ terminal. The pre-pro IGF-2 undergoes post-translational modification by removal of the $\mathrm{N}$ terminal, the addition of sialic acid oligosaccharides to the $\mathrm{E}$ domain and subsequent proteolysis of the $\mathrm{E}$ domain giving rise to various pro-IGF-2. Prohormone convertase converts pro IGF2 to mature IGF-2 (67 amino acids); however, in IGF-2 secreting tumors, an abnormal IGF-2 (87 amino acids) is produced (22). IGF-2 is bound in the circulation to IGFBP-3. About $70-80 \%$ of IGF-2 is transported in the form of a $150 \mathrm{kDa}$ complex consisting of IGF-2, IGFBP-3 and acid-labile subunit (ALS), and $20 \%$ in a $50 \mathrm{k}-\mathrm{Da}$ binary complex of IGF-2 and IGFBP-3. In IGF-2 producing tumors the ratio of the 150 and $50 \mathrm{kDa}$ subunits is reversed. The $50 \mathrm{kDa}$ subunits which are overproduced in NICH have greater biological activity and also can cross 

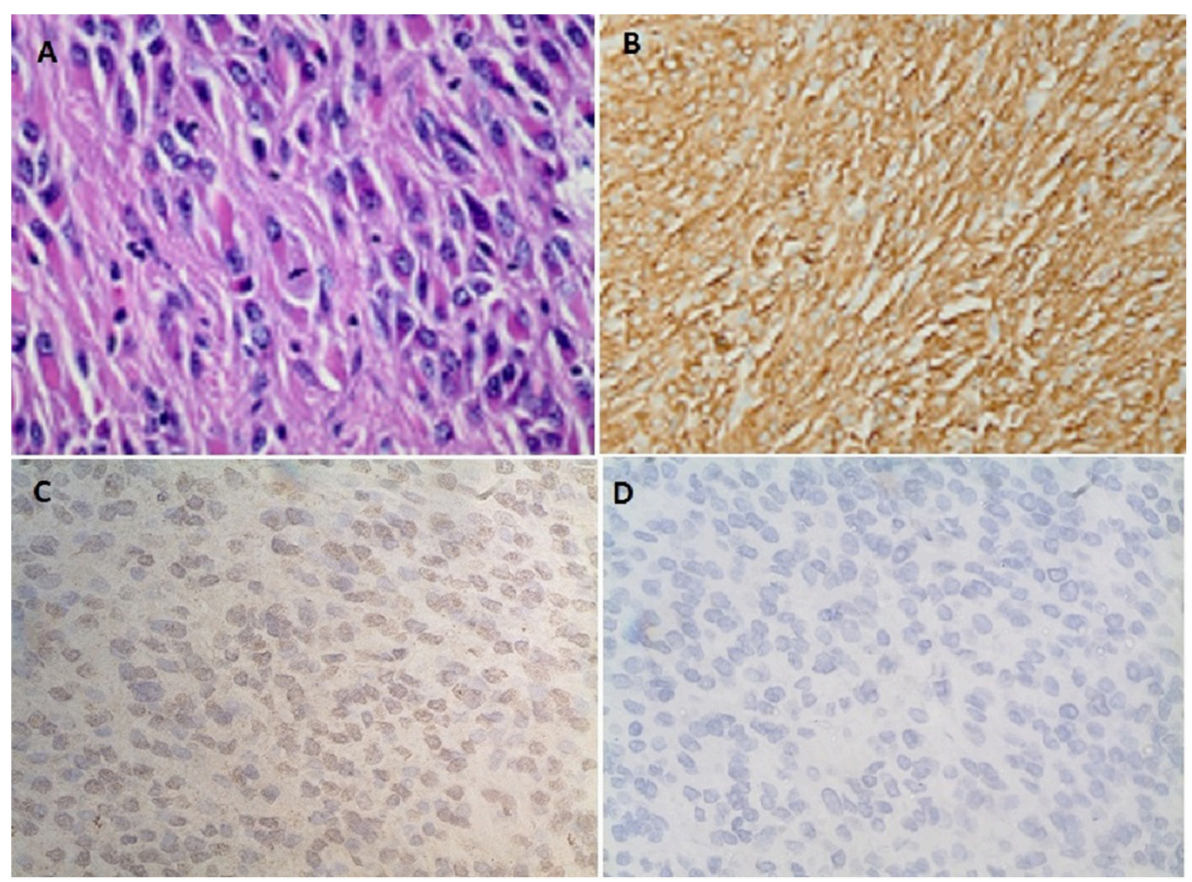

FIGURE 3 | (A) Spindle cells with fibrillary eosinophilic cytoplasm forming whorls consistent with gastrointestinal stromal tumor (GIST). (B) Diffuse positive staining to CD 117. (C) Immunohistochemistry showing diffuse positive staining to IGF-2 monoclonal antibody (MA5-17096, Thermofisher scientific Inc.). (D) No positive staining seen on the control for IGF-2 antibody (MA5-17096, Thermofisher scientific Inc.).

TABLE 2 | Tumors associated with non-islet cell hypoglycemia.

Hepatocellular carcinoma

Fibrosarcoma

Mesothelioma

Adrenocortical carcinoma

Hemangiopericytoma

Stomach carcinoma

Pancreatic carcinoma

Medullary thyroid carcinoma

Lymphoma/Leukemia

Carcinoid syndrome

the capillary membranes to interact with insulin receptors (Figure 4) $(23,24)$.

There are two isoforms of insulin receptor (IR) which are formed due to alternate splicing IR-A and IR-B. IGF-2 can bind with high affinity to both the IGF-1 receptor and insulin receptorA (IR-A) and with low affinity to insulin receptor-B (IR-B). The concentration of a particular isoform of IR is tissue dependent. IR-A expressed more in malignancies and embryonic tissues while IR-B which mediates the metabolic effects of insulin is expressed more in the liver, muscle, and adipose tissue. There are heterologous receptors formed due to heterodimerization of IGF1 receptor and IR. Therefore, the symptoms of NICH depend on not only the level of IGF-2 but also the available concentration of receptors (4).
IGF-2 has multiple actions which can contribute to the development of hypoglycemia (Figure 5). The main mechanism is shutting down hepatic glucose output. Similar to insulin, IGF-2, through activation of the insulin receptor, can inhibit gluconeogenesis, glycogenolysis, and ketogenesis. These actions are mediated through the action on insulin receptors on the hepatocytes and in the hypothalamus which communicate with the liver via the vagal nerve (25-27). IGF-2 also increases the uptake of glucose by muscles and inhibits lipolysis by activating the IR $(28,29)$. Also, growth hormone and IGF-1 levels are suppressed via the activation of IGF-1 receptors in the hypothalamus by IGF-2. Glucagon production is suppressed as well due to the activation of IGF-1 receptors on the pancreatic alpha cells by IGF-2 $(30,31)$. Although glucose consumption by the tumors could contribute to hypoglycemia this does not appear to be a significant pathway (4).

The initial step in the evaluation of hypoglycemia is documenting all components of Whipple's triad, i.e., the presence of signs and symptoms of hypoglycemia, a low plasma blood glucose, and resolution of the symptoms with administration of glucose. A detailed history to evaluate for any systemic diseases or medications which can predispose to hypoglycemia is essential (32).

In order to delineate the etiology of hypoglycemia plasma insulin, C-peptide, proinsulin, and beta-hydroxybutyrate must be drawn when the patient is hypoglycemic. NICH presents with low levels of insulin, C-peptide, proinsulin, and betahydroxybutyrate (Table 3) (32). Further evaluation of $\mathrm{NICH}$ consists of measuring the IGF-1 and IGF-2 levels. IGF-1 is 


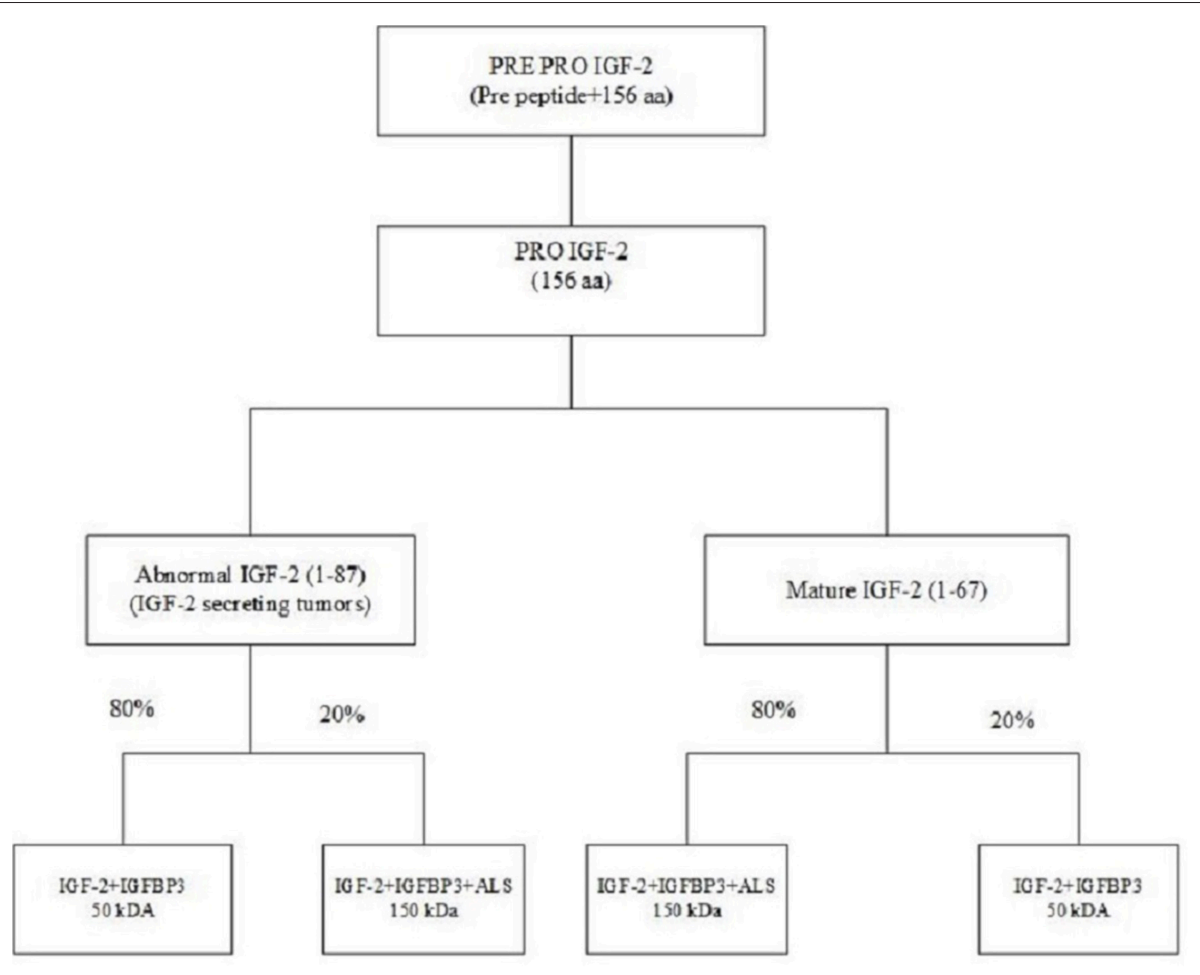

FIGURE 4 | Synthesis and binding of mature and abnormal IGF-2.

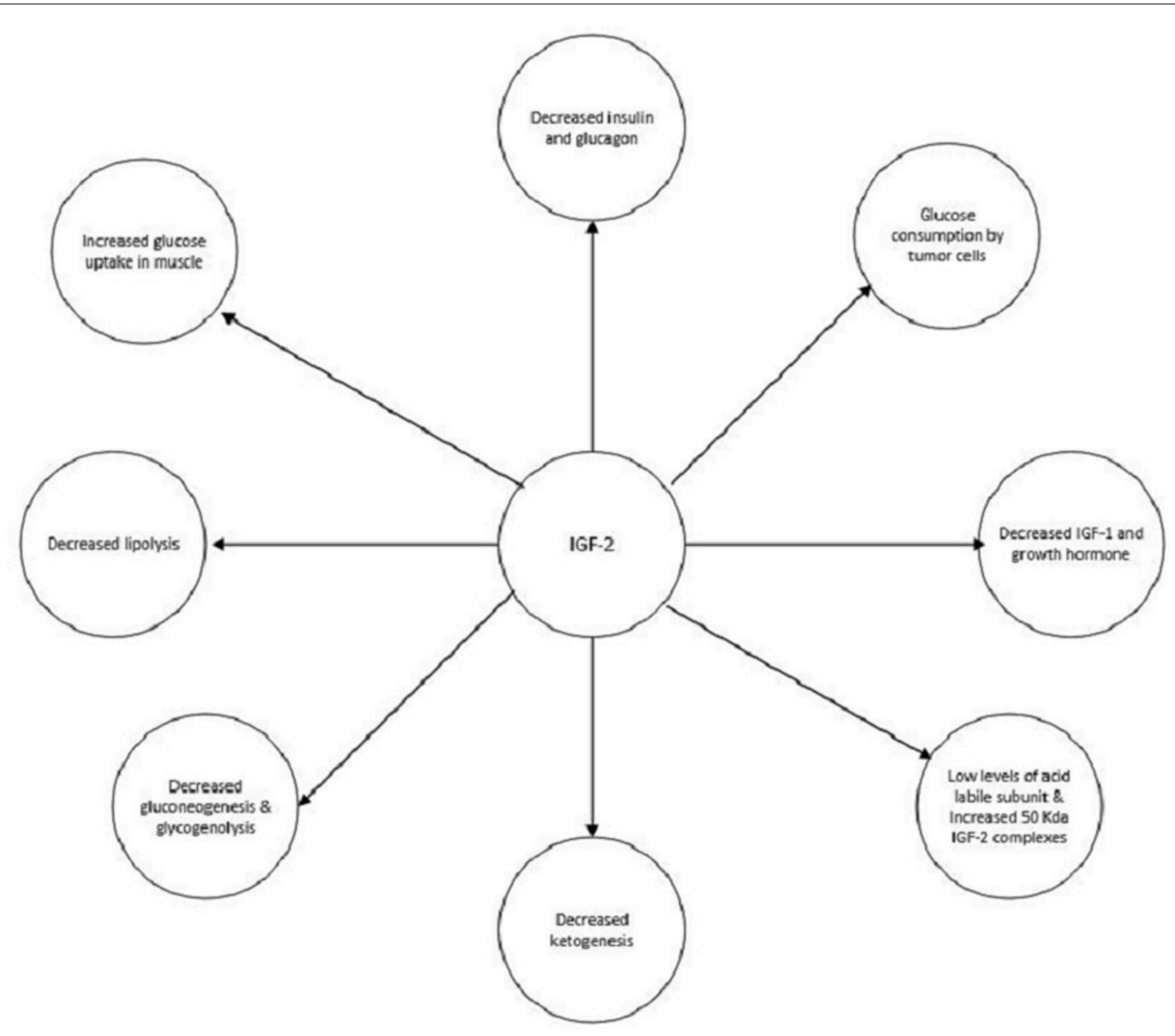

FIGURE 5 | Mechanisms by which IGF-2 induced hypoglycemia. 
TABLE 3 | Differential diagnosis of non-islet cell hypoglycemia.

\begin{tabular}{|c|c|c|c|c|}
\hline & $\begin{array}{l}\text { Insulin } \\
\text { (3 mcu/ml) }\end{array}$ & $\begin{array}{l}\text { C-peptide } \\
(0.2 \mathrm{mmol} / \mathrm{L})\end{array}$ & $\begin{array}{l}\text { Proinsulin } \\
5 \mathrm{pmol} / \mathrm{L}\end{array}$ & $\begin{array}{l}\text { Beta-hydroxybutyrate } \\
\text { ( } 2.7 \mathrm{mmol} / \mathrm{L})\end{array}$ \\
\hline Insulinoma/sulfonylurea & High & High & High & Low \\
\hline Exogenous insulin & High & Low & Low & Low \\
\hline Nonislet cell hypoglycemia & Low & Low & Low & Low \\
\hline Insulin-independent hypoglycemia & Low & Low & Low & High \\
\hline
\end{tabular}

mcu, microunits; mmol, millimole; pmol, picomoles; L, liter; ml, milliliter.

typically suppressed while the levels of IGF-2 may be normal or elevated. An IGF-2/IGF-1 molar ratio of $>10$ confirms NICH. However, it must be kept in mind that IGF-2/IGF-1 ratio may be $>10$ in malnutrition and sepsis; however, in these cases both IGF2 and IGF-1 are low. There is no commercially available assay for pro-IGF-2 $(33,34)$. It must also be noted that the IGF-2/IGF-1 ratio is influenced by the level of IGFBP-3. Therefore, conditions, where the level of IGFBP-3 is reduced like in renal failure, may have a false negative IGF-2/IGF-1 ratio (4).

Surgical excision of the tumor is the most definitive treatment of NICH. It results in an immediate resolution of hypoglycemia as seen in Case 2. Debulking should be considered where complete surgical excision is not feasible $(2,35,36)$. De Boer et al. describes a case of successful treatment of $\mathrm{NICH}$ with neoadjuvant chemoradiation along with embolization of the feeding vessels in a patient with a non-resectable solitary fibrous tumor (37).

Glucocorticoids may be used in the treatment of NICH. They prevent hypoglycemia by increasing hepatic gluconeogenesis, inhibiting peripheral uptake of glucose, and promoting lipolysis (Figure 5).The dose needs to be titrated to manage the hypoglycemia appropriately. As seen in both of our cases, the hypoglycemia resolved to an extent once glucocorticoids administration was started (2). Glucagon increases glycogenolysis and gluconeogenesis and can prevent hypoglycemia. Hoff et al. have used glucagon infusions via a pump to treat $\mathrm{NICH}$ in a patient with meningeal sarcoma. However, effects only last as long as glucagon is administered; therefore it is only a short term treatment (38). Recombinant growth hormone $(\mathrm{rGH})$ by increasing gluconeogenesis and peripheral glucose uptake can alleviate hypoglycemia. They also alter the production of IGF-2 by increasing the $150 \mathrm{kDa}$ complexes and decreasing the $50 \mathrm{kDa}$ complexes. The former is much less efficacious at producing hypoglycemia. $\mathrm{rGH}$ has been used in cases of $\mathrm{NICH}$ which were unresponsive to glucocorticoids (39).

As NICH results from the interaction of big IGF-2 and the insulin receptor, therapies aimed at disrupting this interaction would potentially be useful in the treatment of NICH. Prince et al. have developed a high-affinity antibody to IGF-2 which comprises of human IgG1 Fc domain and a modified domain11 of the IGF-2 receptor (which binds specifically to IGF-2). Substitution of glutamic acid to lysine in the 1,554 position (IGF$2 \mathrm{Re} 1554 \mathrm{k}-\mathrm{Fc}$ protein) further enhances the specificity and affinity for binding to IGF-2 (40). Feng et al. have developed an antibody
(IgG1 m610) which has specificity for both mature and pro IGF-2 (41). Other approaches include enhancing prohormone convertase (which converts pro to mature IGF-2) and use of anti-IGF-2 small interfering RNA $(42,43)$.

\section{CONCLUSION}

$\mathrm{NICH}$ is a rare cause of hypoglycemia however it is one which is likely to be underdiagnosed Physicians need to be vigilant about $\mathrm{NICH}$, as it is increasingly seen, given the increased survival of hepatitis and hepatocellular carcinoma patients. It is also being reported in association with an ever increasing number of cancers. NICH can cause severe hypoglycemia and may present with predominantly neuroglycopenic symptoms. Although altered mental status in a cancer patient could be due to narcotic use, brain metastasis or CNS infections, NICH needs to be in the differential diagnosis.

$\mathrm{NICH}$ is characterized by low levels of insulin, Cpeptide, proinsulin, and beta-hydroxybutyrate. A molar ratio of IGF-2/IGF-1 higher than 10 confirms NICH. Definitive surgery may have to be done for the alleviation of hypoglycemia even though it may not influence the prognosis of cancer. If complete excision is not possible, debulking or embolization should be considered. Glucocorticoids are the preferred medical modality for treatment of $\mathrm{NICH}$ however hypoglycemia recurs once they are stopped, without further definitive treatment.

Further research is needed as to why only a few patients develop NICH, or to establish if there is a critical mass beyond which NICH is likely to occur. Studies are also needed to study the efficacy of newer antibodies.

\section{ETHICS STATEMENT}

This was exempt from ethics committee approval as it is a case report. Written and informed consent was obtained from the patients to submit their cases to the journal.

\section{AUTHOR CONTRIBUTIONS}

VG, HS, and VP were involved in writing the case descriptions and discussion section of the manuscript. CG-S was involved in doing the antibody staining, obtaining pictures and graphs, and also editing the manuscript. JS and LL were involved in editing the manuscript. 


\section{REFERENCES}

1. Cryer P. Hypoglycemia. In: Melmed S, Polonsky K. Braverman L, Kronenberg $\mathrm{H}$, editors. Williams Textbook of Endocrinology. 12th ed. Philadelphia, PA: Elsevier (2011). p. 1568.

2. Teale JD, Wark G. The effectiveness of different treatment options for non-islet cell tumor hypoglycemia. Clin Endocrinol. (2004)60:45760. doi: 10.1111/j.1365-2265.2004.01989.x

3. Seaquist ER, Anderson J, Childs B, Cryer P, Dagogo-Jack S, Fish L, et al. Hypoglycemia and diabetes: a report of a workgroup of the American Diabetes Association and the Endocrine Society. J Clin Endocrinol Metab. (2013)98:1845-59. doi: 10.1210/jc.2012-4127

4. Dynkevich Y, Rother KI, Whitford I, Qureshi S, Galiveeti S, Szulc AL, et al. Tumors, IGF-2, and hypoglycemia: insights from the clinic, the laboratory, and the historical archive. Endocr Rev. (2013)34:798826. doi: 10.1210/er.2012-1033

5. Nader W, Wolfer J. Hepatogenic hypoglycemia associated with primary liver cell carcinoma. Arch Intern Med. (1929)44:70010. doi: 10.1001/archinte.1929.00140050077007

6. Unger RH. The riddle of tumor hypoglycemia. Am J Med. (1966)40:32530. doi: 10.1016/0002-9343(66)90127-6

7. Megyesi K, Kahn CR, Roth J, Neville DM Jr., Nissley SP, Humbel RE, et al. The NSILA-s receptor in liver plasma membranes. Characterization and comparison with the insulin receptor. J Biol Chem. (1975) 250:8990-6.

8. Rinderknecht E, Humbel RE. Primary structure of human insulin-like growth factor II. FEBS Lett. (1978) 89:283-6. doi: 10.1016/0014-5793(78)80237-3

9. Daughaday WH, Emanuele MA, Brooks MH, Barbato AL, Kapadia M, Rotwein P. Synthesis and secretion of insulin-like growth factor II by a leiomyosarcoma with associated hypoglycemia. N Engl J Med. (1988) 319:1434-40. doi: 10.1056/NEJM198812013192202

10. McFadzean AJ, Yeung RT. Further observations on hypoglycemia in hepatocellular carcinoma. Am J Med. (1969) 47:22035. doi: 10.1016/0002-9343(69)90148-X

11. Widmer U, Zapf J, Froesch ER. Is extrapancreatic tumor hypoglycemia associated with elevated levels of insulin-like growth factor II? J Clin Endocrinol Metab. (1982) 55:833-9. doi: 10.1210/jcem-55-5-833

12. Lawson EA, Zhang X, Crocker JT, Wang WL, Klibanski A. Hypoglycemia from IGF2 overexpression associated with activation of fetal promoters and loss of imprinting in a metastatic hemangiopericytoma. J Clin Endocrinol Metab. (2009) 94:2226-31. doi: 10.1210/mend.23.6.9995

13. Yang CQ, Zhan X, Hu X, Kondepudi A, Perdue JF. The expression and characterization of human recombinant proinsulin-like growth factor II and a mutant that is defective in the O-glycosylation of its E domain. Endocrinology. (1996) 137:2766-73. doi: 10.1210/endo.137.7.8770896

14. Dizon AM, Kowalyk S, Hoogwerf BJ. Neuroglycopenic and other symptoms in patients with insulinomas. Am J Med. (1999)106:307-10. doi: 10.1016/S0002-9343(99)00021-2

15. Crocker DW, Veith FJ. Mesodermal tumors associated with hypoglycemia: review of literature and report of a case. Ann Surg. (1965)161:41827. doi: 10.1097/00000658-196503000-00016

16. Fukuda I, Hizuka N, Ishikawa Y, Yasumoto K, Murakami Y, Sata A, et al. Clinical features of insulin-like growth factor-II producing nonislet-cell tumor hypoglycemia. Growth Horm IGF Res. (2006)16:2116. doi: 10.1016/j.ghir.2006.05.003

17. de Groot JW, Rikhof B, van Doorn J, Bilo HJ, Alleman MA, Honkoop $\mathrm{AH}$, et al. Non-islet cell tumour-induced hypoglycaemia: a review of the literature including two new cases. Endocr Relat Cancer. (2007)14: 97993. doi: 10.1677/ERC-07-0161

18. Trivedi N, Mithal A, Sharma AK, Mishra SK, Pandey R, Trivedi B, et al. Non-islet cell tumour induced hypoglycemia with acromegaloid facial and acral swelling. Clin Endocrinol. (1995) 42:433-5. doi: 10.1111/j.1365-2265.1995.tb02654.x

19. Baker J, Liu JP, Robertson EJ, Efstratiadis A. Role of insulin-like growth factors in embryonic and postnatal growth. Cell. (1993)75:7382. doi: 10.1016/S0092-8674(05)80085-6

20. Stylianopoulou F, Herbert J, Soares MB, Efstratiadis A. Expression of the insulin-like growth factor II gene in the choroid plexus and the leptomeninges of the adult rat central nervous system. Proc Natl Acad Sci USA. (1988) 85:141-5. doi: 10.1073/pnas.85.1.141

21. Sussenbach JS, Steenbergh PH, Holthuizen P. Structure and expression of the human insulin-like growth factor genes. Growth Regul. (1992)2:1-9.

22. Duguay SJ, Jin Y, Stein J, Duguay AN, Gardner P, Steiner DF. Posttranslational processing of the insulin-like growth factor-2 precursor. Analysis of O-glycosylation and endoproteolysis. J Biol Chem. (9817) 273:1844351. doi: 10.1074/jbc.273.29.18443

23. Rosenfeld RG, Hwa V, Wilson E, Plymate SR, Oh Y. The insulin-like growth factor-binding protein superfamily. Growth Horm IGF Res. (2000) 10 (Suppl. A):S16-7. doi: 10.1016/S1096-6374(00)90007-8

24. Zapf J. Insulin-like growth factor binding proteins and tumor hypoglycemia. Trends Endocrinol Metab. (1995) 6:37-42. doi: 10.1016/1043-2760(94)00144-S

25. Jakob A, Meyer UA, Flury R, Ziegler WH, Labhart A, Froesch ER. The pathogenesis of tumour hypoglycaemia: blocks of hepatic glucose release and of adipose tissue lipolysis. Diabetologia. (1967)3:506-14. doi: 10.1007/BF01213569

26. Cherrington $\mathrm{AD}$. The role of hepatic insulin receptors in the regulation of glucose production. J Clin Invest. (2005)115:1136-9. doi: 10.1172/JCI25152

27. Puglianiello A, Cianfarani S. Central control of glucose homeostasis. Rev Diabet Stud. (2006)3:54-60. doi: 10.1900/RDS.2006.3.54

28. Alexandrides T, Moses AC, Smith RJ. Developmental expression of receptors for insulin, insulin-like growth factor I (IGF-I), and IGF-II in rat skeletal muscle. Endocrinology. (1989)124:1064-76. doi: 10.1210/endo-124$2-1064$

29. Froesch ER, Zapf J. Insulin-like growth factors and insulin: comparative aspects. Diabetologia. (1985)28:485-93. doi: 10.1007/BF002 81982

30. Frohman LA, Jansson JO. Growth hormone-releasing hormone. Endocr Rev. (1986)7:223-53. doi: 10.1210/edrv-7-3-223

31. Frohman LA, Downs TR, Chomczynski P. Regulation of growth hormone secretion. Front Neuroendocrinol. (1992)13:344-405.

32. Cryer PE, Axelrod L, Grossman AB, Heller SR, Montori VM, Seaquist ER, et al. Evaluation and management of adult hypoglycemic disorders: an endocrine society clinical practice guideline. J Clin Endocrinol Metab. (2009) 94:70928. doi: $10.1210 /$ jc.2008-1410

33. Teale JD, Marks V. Inappropriately elevated plasma insulin-like growth factor II in relation to suppressed insulin-like growth factor I in the diagnosis of non-islet cell tumor hypoglycemia. Clin Endocrinol. (1990)33:8798. doi: 10.1111/j.1365-2265.1990.tb00469.x

34. Clark MA, Hentzen BT, Plank LD, Hill GI. Sequential changes in insulinlike growth factor 1, plasma proteins, and total body protein in severe sepsis and multiple injury. JPEN J Parenter Enteral Nutr. (1996) 20:36370. doi: 10.1177/0148607196020005363

35. Zapf J, Futo E, Peter M, Froesch ER. Can "big" insulin-like growth factor II in the serum of tumor patients account for the development of extrapancreatic tumor hypoglycemia? J Clin Invest. (1992) 90:257484. doi: 10.1172/JCI116152

36. Kotani K, Tsuji M, Oki A, Kashihara T, Yamada K, Kawakami F, et al. IGFII producing hepatic fibrosarcoma associated with hypoglycemia. Intern Med. (1993) 32:897-901. doi: 10.2169/internalmedicine.32.897

37. de Boer J, Jager PL, Wiggers T, Nieboer P, Machteld Wymenga AN, Pras E, et al. The therapeutic challenge of a nonresectable solitary fibrous tumor in a hypoglycemic patient. Int J Clin Oncol. (2006)11:478-81. doi: 10.1007/s10147-0060606-1

38. Hoff AO, Vassilopoulou-Sellin R. The role of glucagon administration in the diagnosis and treatment of patients with tumor hypoglycemia. Cancer. (1998) 82:1585-92. doi: 10.1002/(SICI)1097-0142(19980415)82:8\&lt

39. Drake WM, Miraki F, Siddiqi A, Yateman M, Barnes NC, Camacho-Hübner C, et al. Dose-related effects of growth hormone on IGF-I and IGF-binding protein-3 levels in non-islet cell tumour hypoglycaemia. Eur J Endocrinol. (1998)139:532-6. doi: 10.1530/eje.0.1390532

40. Prince SN, Foulstone EJ, Zaccheo OJ, Williams C, Hassan AB. Functional evaluation of novel soluble insulin-like growth factor (IGF)-II-specific ligand traps based on modified domain 11 of the human IGF2 receptor. Mol Cancer Ther. (2007) 6:607-17. doi: 10.1158/1535-7163.MCT-06-0509 
41. Feng Y, Zhu Z, Xiao X, Choudhry V, Barrett JC, Dimitrov DS. Novel human monoclonal antibodies to insulin-like growth factor (IGF)-II that potently inhibit the IGF receptor type I signal transduction function. Mol Cancer Ther. (2006) 5:114-20. doi: 10.1158/1535-7163.MCT-05-0252

42. Qiu Q, Basak A, Mbikay M, Tsang BK, Gruslin A. Role of pro-IGF-II processing by proprotein convertase 4 in human placental development. Proc Natl Acad Sci USA. (2005) 102:11047-52. doi: 10.1073/pnas. 0502357102

43. Riedemann J, Macaulay VM. IGF1R signaling and its inhibition. Endocr Relat Cancer. (2006) 13 (Suppl. 1):S33-43. doi: 10.1677/erc.1. 01280
Conflict of Interest Statement: The authors declare that the research was conducted in the absence of any commercial or financial relationships that could be construed as a potential conflict of interest.

Copyright $\odot 2019$ Garla, Sonani, Palabindala, Gomez-Sanchez, Subauste and Lien. This is an open-access article distributed under the terms of the Creative Commons Attribution License (CC BY). The use, distribution or reproduction in other forums is permitted, provided the original author(s) and the copyright owner(s) are credited and that the original publication in this journal is cited, in accordance with accepted academic practice. No use, distribution or reproduction is permitted which does not comply with these terms. 